\title{
Kış Turizmi Destinasyonunda Yaşanan Unutulmaz Turizm Deneyimleri: Kültürlerarası Karşılaştırma
}

\section{Memorable Tourism Experiences in Winter Tourism Destination: A Cross- National Comparison}

\author{
Yrd. Doç. Dr. Gülizar AKKUŞ \\ Kastamonu Üniversitesi \\ Turizm Fakültesi \\ E-posta: gakkus@kastamonu.edu.tr \\ Orcid Id: 0000-0001-9262-2680
}

\section{Öz}

Turizm ürününün değeri, deneyime dayanmaktadır. Turistin yaşadığı bir deneyim ne kadar unutulmaz olursa, turizm merkezleri o ölçüde başarıya ulaşmaktadır. Bu sebeple destinasyonların öncelikle hitap ettiği turistik kitleye yönelik unutulmaz deneyimler sunması ve bu deneyimleri nasıl arttırabileceğini keşfedebilmek için profil araştırması yapması gerekmektedir. Bu araştırmada, kış ve spor turizmi amacıyla Erzurum'u ziyaret eden Polonyalı ve İranlı turistlerin yaşadığı unutulmaz deneyimler değerlendirilmiş ve turistlerin milliyetlerine göre bu deneyimlerin farklılaştığı noktalar tespit edilmeye çalışılmıştır. Hazırlanan anket formları kayak sezonunda Erzurum havaalanı dış hatlar giden yolcu bölümündeki yabancı turistlere uygulanmıştır. Toplamda 418 anket formu değerlendirmeye alınmıştır. Araştırma sonucunda, Polonyalı turistlerin, haz (hedonizm) ve anlamlılık açısından yaşadıkları deneyimi, İranlı turistlerden daha olumlu algıladığı belirlenmiştir.

Anahtar Kelimeler: Unutulmaz turizm deneyimleri, Turist deneyimi, Kış turizmi destinasyonu, Kültürlerarası karşılaştırma.

\section{Abstract}

The value of tourism product is based on experience. Tourism centres succeed in the sense of unforgettable tourist experience. For this reason, it is necessary to provide memorable experiences for the tourist mass which the destinations are primarily addressed and explore the profile to discover how it can enhance these experiences. In this study, memorable experiences of Polish and Iranian tourists visiting Erzurum in winter and sports tourism were evaluated and the points that these experiences differed according to the nationalities of the tourists. The prepared questionnaire forms were applied to the foreign tourists during the ski season. A total of 418 questionnaires were evaluated. As a result of the research, it was determined that Polish tourists perceive the experience in terms of hedonism and meaningfulness more positively than Iranian tourists.

Keywords: Memorable tourism experience, Tourist experience, Winter tourism destination, Cross-national comparison. 


\section{Giriş}

İlk defa 1960'larda kaydedilen deneyim kavramı, bir kişinin günlük yaşamda sahip olduğu belirli bir oluşumu ifade eden son derece belirsiz bir terim iken, 1982 yılında Holbrook ve Hirschman'ın yeni ufuklar açan çalışması ile deneyim kavramı pazarlama literatürüne girmiştir. Çalışmada, tüketici davranışlarının sadece bilgi işlem tabanlı olmadığı, duygusal tüketim deneyiminde aktif bir katıımın olduğu varsayılmıştır. Bu durum, özellikle 1990'larda Pine ve Gilmore'un deneyim ekonomisi de dâhil olmak üzere bir dizi farklı kilit kavramın ortaya çıkmasına yol açmıştır.

Pine ve Gilmore (1999), ünlü terimleri deneyim ekonomisini kitaplaştırmış ve pazarlama alanında yeni bir çağı işaret eden en ufuk açıcı katkılardan birini sağlamıştır. Temel önermeleri, tüketicilerin tüketim bağlamında ve ekonomik değer sürecinde unutulmaz deneyimler peşinde olduğudur (Neuhofer ve Buhalis, 2014: 125126). Deneyim kavramının 2000'li yılların en büyük terimlerinden biri olarak kabul edilmesi (Smith, 2009: 15) ile birlikte küreselleşme, teknolojik gelişmeler ve yoğunlaştırılmış rekabete maruz kalan şirketler sunularını farklılaştırmak için yeni yollar bulmak zorunda kalmıştır (Prahalad ve Ramaswamy, 2004: 7). Buna dayanarak, uygulayıcılar ve akademisyenlerin ortak görüşü, müşteri deneyiminin marka, ürün ve hizmetlerin başarısında belirleyici bir faktör olduğu yönünde gelişmiştir (Stickdorn, 2014: 329).

Günümüzde hala turizmin maddi unsurları önde gelse de, alternatif turizm türlerinin popülerleşmesine denk düşen 1990'lı yılların ortalarında deneyimsel turizm düşüncesi kesin bir boyut kazanmıştır (Stamboulis, 2008: 162). Büyüyen bu trendi ölçmeye yönelik fazla çalışma olmamakla birlikte, turizm yayınları ve literatürü bu talep karşısında odağını yeni yeni değiştirmektedir (Edgell ve diğ., 2014: 29).

$\mathrm{Bu}$ araştırmada, turistlerin unutulmaz turizm deneyimlerini araştırmak amaçlanmıştır. Bu amaca ulaşmak için, kış turizmine katılmak için Erzurum'u ziyaret eden yabancı turistlerin yaşadığı turistik deneyimler değerlendirilmiş ve turistlerin milliyetlerine göre unutulmaz deneyimlerin ne gibi farklılıklar taşıyabileceği tespit edilmeye çalışıımıştır. Bu sayede hem literatüre katkı sağlamak hem de destinasyon paydaşlarına ipucu olabilecek sonuçlar ortaya koyarak yönetsel bir etkiye sebep olmak planlanmıştır.

\section{Literatür Taraması}

\subsection{Turizm Deneyimleri}

Turizm bağlamında deneyimler, başlangıçta yenilik arayışı ve gündelik yaşamın zıddı olarak tasvir edilmiştir. Bu ilk girişimler, turizm deneyimi yapısına yönelik daha bütünsel bir anlayış geliştirmek amacıyla, araştırmacılar tarafından takip edilmiştir (Otto ve Ritchie, 1996: 165-174). Sosyal bilimlerden farklı sayısız yaklaşıma rağmen, turizm deneyiminin tek bir tanımı üzerinde bile bugüne kadar bir fikir birliği sağlanamamıştır. Bunun yerine, deneyimin karmaşıklığının kabul edilmesi gerektiği görüşüne varıımıştır.

Bir dizi turizm kaynağı ve paydaşı dolaylı olarak "turizm deneyimi" terimini kullanırken, bazı yazarlar "turist deneyimi" kavramını tanımlamaya çalışmıştır (Jennings ve diğ., 2009: 300). Çeşitli karmaşık unsurları kapsayan turizm deneyimi ya da turist deneyiminin özlü bir tanımına ulaşmak oldukça zordur (Selstad, 2007: 21). Genel olarak yazarların konuya bakış açıları ve buradan yola çıkarak yaptıkları birbirinden farklı tanımlamalardan bazıları şu şekildedir; 
Li (2000: 864-866) turizm deneyiminin suni ve oluşturulmuş bir tüketim hareketi, sıradan yaşamın sorunlarına bir yanıt, özgünlük arama ve çok yönlü bir eğlence etkinliği olduğunu söylemiştir. Stamboulis ve Skayannis (2003: 41) turist deneyimini, deneyimin meydana geldiği bir 'tiyatro' olarak görülen destinasyonlar ile kendilerini kaptırma derecelerine göre rolünü oynayan 'aktörler' olan turistler arasındaki etkileşimden doğan deneyimler olarak ifade etmiştir. Larsen'e (2007: 15) göre turist deneyimi, uzun süreli belleğe girecek kadar güçlü geçmiş kişisel seyahatler ile ilgili etkinliklerdir. O'dell (2007: 41) ise, fiziksel olarak insanı etkileyen ve olağanüstü bir şeye katılmış algısı bırakan, gündelik hayatın basit bir devamından daha fazlası olabileceğini vurgulamıştır. Selstad (2007: 20), bireysel olarak kimlik arayışı ve kendini gerçekleştirme arayışı ile yakından bağlantılı, estetik ve eylemlerin sembolik gösterimine yol açacak sürekli bir algı akışı içeren bir yenilik ve aşinalık kombinasyonu olarak tanımlanabileceğini ifade etmiştir.

Genel olarak, turist deneyimlerinin tamamen toplumsal olarak yapılandırılmış (Tussyadiah ve Fesenmaier, 2009: 24) intiyaçlara yönelik bir pazarlama düzenlemesi olarak kavramsallaştırıldığı söylenebilir (McCabe, 2014: iii). Bununla birlikte, sosyal olarak inşa edilmiş turist deneyimlerinin niteliği, sembolizm (anlam, hisler ve duygu), sosyalleşme (yerel halk ile birlikte olma, katılım) ve anılar gibi bir dizi niteliği kapsamaktadır (Batat ve Frochot, 2014: 115).

Turistler aynı anda birçok intiyacını tatmin etmek için kompleks bir ürünü ziyaret etmeyi ister. Bu nedenle turizm ürünü ağırlıklı olarak deneyimsel bir ürün olarak görülür (Goldsmith ve Tsiotsou, 2012: 208). Yani deneyimler, geleceğin turizm ürünleridir (Arsenault ve Gale, 2004: 1).

\subsection{Turizm Deneyimi Araştırmaları}

Deneyim, turizm ürününün önemli bir unsuru olarak kabul edilse de, nadiren açık bir şekilde ele alındığı gözlenmektedir (Stamboulis, 2008: 162). 2000-2009 yılları arasında temel turizm dergilerinde yayınlanan makaleler incelendiğinde, yayınlanan 2645 makalenin sadece 263 tanesinde turizm deneyimlerine odaklanıldığı, bunun da toplam makaleler içerisindeki oranının yaklaşık \%9,9 olduğu tespit edilmiştir (Ritchie ve diğ., 2011: 423-424). Turizm deneyimlerine ilişkin mevcut literatür, yüksek riskli macera aktivitelerindeki katıımcı deneyimleri yanı sıra, doğal alanlarda, otelcilik hizmetlerinde ve tarihi mekanlarda turistlerin deneyimlerinin kişisel ve duygusal boyutları üzerine odaklanmaktadır. Turizm deneyimlerinin gerçekleştirildiği alan ve mekânlar çeşitlendirildiği gibi, ilgili literatürün önemli bir bölümü turizm deneyimlerinin belirleyicileri ile ilgilenmektedir.

Turizm hizmetleri, benzersiz ve yüksek derecede duygusal deneyimler sağlayarak, müşteri memnuniyetine ve oldukça yüksek seviyelerde bir sadakat oranına ulaştırabiliyorken, turizm pazarlaması literatürü bu stratejik yönelimi henüz benimsemiş değildir (Goldsmith ve Tsiotsou, 2012: 212-213). Ancak son yıllarda ilgi çekici, kişisel, sosyal açıdan tatmin edici ve unutulmaz olarak ifade edilen deneyimsel turizm ile ilgili çokça tartışma yapılmaktadır. Uygulamada turizm deneyimlerine artan ilgi, turistlere ne sunulduğundan çok turistlerin hislerine hitap eden yollara daha fazla dikkat edilmesi anlamına gelmektedir (Rettie, 2013: 72).

Turizm deneyimi ile ilgili kavramsal ve ampirik çalışmalara yönelik geniş kapsamlı bir literatür taraması ardından, çalışmaların 90'lı yıllarda başladığı fakat 2000 'li yıllarda büyük bir ivme kazandığı görülmüştür. Özellikle 2009 yılı ve sonrasında yapılan çalışmaların artmış olması, konuya verilen önemin arttığının bir göstergesidir. 
Genel olarak çalışmalarda irdelenen deneyim konusu, belirli turistik çekiciliklere ya da ürünlere yönelik ziyaretçi deneyimi, seyahat deneyimi ve tüketici deneyimi olmakla birlikte, turistlerin geçmiş deneyimlerini ya da duygusal deneyimlerini incelemeye yönelik yapılmış araştırmalar da bulunmaktadır. Daha spesifik olarak değerlendirilecek olursa, çalışmalarda deneyimin gerçekleştirildiği alan ve mekânlar büyük bir çeşitlilik göstermektedir. Ancak en sık ölçüme tabi tutulan uygulama alanları, konaklama işletmeleri; kahve ve müzik gibi temalara sahip çeşitli festivaller; kırsal turizm, yaban hayatı turizmi gibi ekoturizm aktivitelerine imkân sağlayan alanlar; kültür mirası parkları ve tarihi semtler gibi tarihi mekânlar; müzeler ve sanat galerileri gibi kültürel faaliyetlerin gerçekleştirildiği yerler; değişik restoranlar ve gastronomik deneyimler sunan özel mekânlar; şarap turizmi rotaları; hayvanat bahçesi, akvaryum ve tema park ya da milli park gibi rekreasyonel alanlar olarak sıralanabilir. Bunun yanı sıra, kış parkı ya da kar parkları, kış sporuna imkân sağlayan alanlar ve dağcılık gibi macera turizmine yönelik faaliyetlerin gerçekleştirildiği alanlara yönelik deneyimsel çalışmalar da göze çarpmaktadır. Turizm deneyimi araştırmalarının çoğunda nicel araştırma tekniği kullanılmış olup, örneklem olarak talebe yönelik kitle yani turistler tercih edilmiştir. Paydaşlara yönelik çalışmalar ise, oldukça düşük bir orana sahiptir (Akkuş, 2016: 188-189).

Turizm araştırmalarında kültürlerarası karşılaştırmalar sıklıkla görülmekte olup, farklı milliyetlerin farklı turistik davranışlar sergilediğine ilişkin birçok çalışma bulunmaktadır. Pizam ve Reichel (1995; 1996) 63 Hollandalı tur rehberi ile yaptığı araştırmada, rehberlerin Fransa, İtalya, Japonya ve Amerika'dan gelen farklı turist gruplarının davranışlarını değerlendirmesini istemiştir. Turistlerin milliyetlerine bağlı olarak, 20 davranışsal özellikten 18'inin belirgin olarak farklı olduğunu tespit etmişlerdir. İtalyan ve Amerikalı turistler ile Japon ve Fransız turistlerin benzer davranışlar sergilediği sonucuna ulaşmışlardır. Pizam ve Jeong (1996) ise Asyalı popülasyonunu arttırarak Amerikan, Japon ve Koreli turistleri karşılaştırmıştır. Birleşik Devletler gibi bireyci kültürlerden gelenlerin, kollektivist kültürlerden gelen turistlere göre daha dinamik ve aktif turizm faaliyetlerini tercih ettiği tespit edilmiştir. Reisinger vd. (2009) önemli cazibe merkezlerini ziyaret eden Batılı ve Asyalı turistlerin destinasyon niteliklerini değerlendirme ve tüketim davranışı açısından kültürel farklılıklar sergilediğini tespit etmiştir. Asyalı turistler, güvenli mekanlara ve etkinliklere katılmayı tercih etmekte ve yabancılarla sosyal etkileşimden kaçınmakta iken, aksine Batılı ziyaretçilerin yeni deneyimler aradığı ve riski hesaplayarak daha zorlu etkinliklere katıldığı sonucuna ulaşılmıştır.

Kozak (2001) yaptığı bir araştırmada Mayorka ve Türkiye'yi ziyaret eden 1872 İngiliz ve Alman turistin memnuniyet düzeyi arasında fark olup olmadığını belirlemeyi amaçlamıştır. Konumlar arasında farklılık olup olmadığını test etmek için anket iki destinasyonda da uygulanmıştır. Bulguların analizi, İngiliz turistlerin neredeyse tüm bireysel özellikleri ile memnun olma olasılığının Alman turistlere göre daha yüksek olduğunu göstermiştir. Kozak (2001) yaptığı geniş kapsamlı kültürlerarası araştırmada memnuniyete odaklanırken, Oral ve Çelik (2013) Kapadokya'yı ziyaret eden Uzak Doğulu (Japonya, Güney Kore ve Çin) turistlerin estetik deneyimleri ve bunun tatmin düzeyi üzerindeki etkisini araştırmıştır. Araştırma neticesinde, turistik ürünlere yönelik estetik değer deneyimi ile müşteri tatmini arasında pozitif bir ilişkinin olduğu tespit edilmiştir.

Kay (2009) Melbourne, Avustralya'yı ziyaret eden Batılı ve Asyalı turistlerin kültürel deneyimlere yönelik motivasyonlarına ilişkin bir ölçüm modeli geliştirmeyi amaçlamıştır. Bununla birlikte Batılı ve Asyalı turistler arasındaki belirli kültürel dil grubu farklılıkları da dikkate alınmıştır. Asyalı turistler Çince ve Japonca konuşanlar 
olarak ayrılmış, ancak İngilizce konuşan Batılı turistler farklı kültür grubunda değerlendirilmemiştir. Araştırma sonucunda, Batılı ve Asyalı turistler arasında önemli kültürel farklılıklar bulunmazken, İngilizce konuşan turistler arasında kültürel deneyime katılma nedenleri bakımından önemli farklılıklar tespit edilmiştir.

Kim (2012) film turizmine katılan turistlerin deneyimlerine ilişkin kültürlerarası bir araştırma yapmıştır. Tarihi bir Kore televizyon dizisinin geçtiği Daejanggeum Tema Parkı'na gelen Çinli, Japon, Tayvanlı ve Taylandlı ziyaretçilere anket uygulamıştır. Yapılan analizler sonucunda milliyetin, turistlerin yaşadığı deneyimi etkilediği tespit edilmiştir. Film turizmi deneyiminde "yenilik ve presti", "ekran deneyiminden öte ve yeniden canlandırma" ile "yakınlık ve hatıra" olmak üzere üç belirgin boyut tanımlanmıştır.

\section{Araştırma Yöntemi}

\subsection{Evren ve Örneklem}

Türkiye'nin birinci derecede önemli ve öncelikli Alpin destinasyonlarından biri olan Erzurum ili, kent merkezi ve yakın çevresinde, Palandöken dağları, Erzurum boğazı mevkii, Gez yaylası ve Konaklı bölgesi olmak üzere birçok kış ve spor turizm merkezini barındırmaktadır (Toy ve diğ., 2010: 3). Palandöken dağları, uluslararası bir istasyon olma özelliği ile birlikte, Erzurum kent merkezinde kış sporlarına olanak sağlamaktadır. Alp disiplininin rahatlıkla uygulandığı kayak tesisleri, geniş ve uzun pistleri ile kar kalitesi açısından sporcular için de oldukça çekici olarak tasvir edilmektedir.

Erzurum'un bu araştırma kapsamına alınmasındaki neden, kış turizminin gelişmiş olması ve bir marka olarak değerlendirilmesidir. Ayrıca bölgenin kış turizmini destekleyecek otantik özelliklere sahip olması da önemli bir avantaj sağlamaktadır. Bu sayede gelen turistlere unutulmaz bir kış tatili sunulabileceği göz önüne alınarak, araştırma kapsamı Erzurum olarak belirlenmiştir. Araştırmanın evrenini kış ve spor turizmi amacıyla Erzurum'a gelen İranlı ve Polonyalı turistler oluşturmaktadır. Bunun sebebi, Erzurum İ Kültür ve Turizm Müdürlüğünden elde edilen bilgiler doğrultusunda 2014 yılı kış sezonunda Erzurum'a en çok bu iki milliyetten yabancı turistin gelmiş olmasıdır (İran: 7580, Polonya: 3495). Evrenin tamamına ulaşılması imkan dahilinde olmadığı, maliyet ve zaman açısından sıkıntı yaratacağı göz önüne alınarak örnekleme yoluna gidilmiştir (Özmen, 2009: 171-172, 181). Araştırmada tesadüfi olmayan örnekleme yöntemlerinden kolayda örnekleme yöntemi tercih edilmiştir. Araştırmanın \%95 güven aralığında 0,05 önem seviyesinde 372 kişiye yapılması uygun bulunmuştur (Altunışık ve diğ., 2012: 137). Oluşabilecek cevaplama hataları göz önüne alınarak 420 anket formu dağıtılmasına karar verilmiştir.

\subsection{Veri Toplama Yöntemi}

Kesin anket formu hazırlanıp veri toplamaya geçmeden önce araştırma örneğini temsil edecek 20 yabancı turist ile 2014 yılı Aralık ayında bir pilot çalışma yapılmıştır. Ölçeğin orjinal hali İngilizce olduğu ve İngilizce artık tüm dünyada bilinirliği kabul edilen ortak dillerden biri olarak görüldüğü için pilot çalışmada sadece İngilizce anketler uygulanmıştır. İngilizce bilgisi iyi olan katılımcılara ölçeğin uygunluğunu ve anlaşılırlığını belirtmeleri istenmiştir. Pilot çalışma esnasında İranlı turistlerin İngilizce okuma ve anlama seviyelerinin yeterli olduğu, ancak Polonyalı turistlerin oldukça zorlandığı gözlenmiştir. Pilot çalışma sırasında sadece İngilizce seviyesi iyi olan turistlere ulaşılabilmiştir. Bu sebeple tüm potansiyel görüşmelerin değerlendirilebilmesi adına anketler Lehçeye de çevrilmiştir. Bu aşamada ölçek çevirilerinde en sık 
kullanılan yaklaşımlardan biri olan geleneksel yaklaşım (Hançer, 2003: 50) ile Lehçeye çevrilen ölçeğin güvenilir, geçerli ve aslına uygun olup olmadığı kontrol edilmiştir. Öncelikle ölçek İngilizceden Lehçeye çevrilmiştir. Ardından çevrilen bu ölçek tekrar orijinal dile geri çevrilmiştir. Bu iki çeviri arasındaki eşitlik her iki dili de konuşan örneklemler üzerinde denenmiş ve uygunluğu kabul edilmiştir.

Hazırlanan anket formları Erzurum havaalanı dış hatlar giden yolcu bölümünde turistlere, pasaport kontrolünü geçtikten sonra uçağa binmeden önceki bir saatlik boş zaman diliminde elden dağıtııp toplanmıştır. Anketler havaalanında uygulandığı için Valilik ve Emniyet Müdürlüğünden gerekli izinler alınmış ve araştırma 1 Ocak-15 Şubat 2015 tarihleri arasında yürütülmüştür. Araştırma kapsamında toplam 420 yabancı turiste ulaşılabilmiş ve eksik doldurulan anketlerin elenmesi sonucu toplam 418 form analize tabi tutulmuştur.

\subsection{Kullanılan Ölçek}

Kapsamlı literatür taraması sonucu, turizm deneyimlerine ilişkin çalışmalar değerlendirilmiş ve metodolojiye yönelik kıstaslar da göz önüne alınarak, araştırmada Jong-Hyeong Kim'in unutulmaz turizm deneyimleri ölçeğinin kullanılması uygun bulunmuştur. Kim (2009) ilk olarak doktora tezinde geçerli ve güvenilir bir unutulmaz turizm deneyimi ölçeği geliştirmeyi ve deneyim ile davranışsal niyet arasındaki yapısal ilişkiyi incelemeyi amaçlamıştır. Churchill (1979) ve Hinkin (1995)'in önerdiği ölçek geliştirme sürecini takip ederek, temel bileşenler analizi ile toplam varyansı \%74 olan yedi faktör belirlemiştir. Bunlar haz (hedonizm), yenilenme, yerel kültür, anlamlılık, bilgi, katılım ve yenilik olarak adlandırılmıştır. Ardından Ritchie ve McCormick (2012) ile yaptığı çalışmada, 24 soruluk unutulmaz turizm deneyimleri ölçeğinin çoğu destinasyon için uygulanabilir olduğunu doğrulamıştır. Kim ve Ritchie (2014) bir sonraki çalışmalarında, geliştirdikleri unutulmaz turizm deneyimi ölçeğinin kültürlerarası geçerliliğini kanıtlamışlardır. Kim (2014) son çalışmasında ise, unutulmaz turizm deneyimleri yaratan destinasyon özelliklerini kavramsallaştıran bir ölçek geliştirmiştir.

Unutulmaz turizm deneyimleri ölçeğine dayalı olarak geliştirilen anket formu iki bölümden oluşmaktadır. İlk bölümde, turistlerin tatilleri süresince yaşadıkları deneyimleri değerlendirmek amacıyla yedili sıralı ölçekte (1="Yeterince deneyimlemedim"; 7="Oldukça çok deneyimledim") 24 ifadeye yer verilmiştir. Diğer kısımda ise, yanıtlayıcıların demografik özelliklerini tespit etmek amacıyla cinsiyetleri ve yaşlarını belirtmeleri istenmiştir. Demografik değişkenlere ilişkin bir analiz yapılması planlanmadığı için katıımcılara meslek ya da eğitim durumlarına ilişkin bilgiler sorulmamıştır.

\section{Bulgular}

\subsection{Demografik Özellikler}

Tablo 1: Katılımcıların Demografik Özelliklerine İlişkin Bulgular

\begin{tabular}{|l|c|c|l|c|c|}
\hline & Frekans (f) & Yüzde (\%) & & Frekans (f) & Yüzde (\%) \\
\hline Milliyet & 257 & 61,5 & $15-24$ & 62 & 14,8 \\
\hline Polonya & 161 & 38,5 & $25-34$ & 165 & 39,5 \\
\hline İran & 418 & 100 & $35-44$ & 110 & 26,3 \\
\hline Toplam & & $45-54$ & 53 & 12,7 \\
\hline Cinsiyet & 220 & 52,6 & 55 ve üzeri & 28 & 6,7 \\
\hline Erkek & 198 & 47,4 & Toplam & 418 & 100 \\
\hline Kadın & 418 & 100 & \multicolumn{3}{|l|}{} \\
\hline Toplam &
\end{tabular}


Toplam 418 yabancı turistin 257'si Polonyalı ve 161'i İranlıdır. Turistlerin 198'i kadın, 220'si erkek olup, \%39,5 ile büyük yoğunluğu 25-34 yaş aralığındadır. Bunu takiben \%26,3 ile en çok 35-44 yaş arasındaki kişilerin kış turizmi amacıyla geldiği belirlenmiştir.

\subsection{Doğrulayıcı Faktör Analizi}

Unutulmaz turizm deneyimleri ölçeğinin uygunluğunu test etmek amacıyla doğrulayıcı faktör analizi yapılmıştır. Faktör analizi öncesinde verilerin normal dağılım gösterip göstermediğine bakılmıştır. Yapılan çarpıklık hesaplaması sonucunda verilerin $\pm 1,96$ arasında olduğu gözlenmiş ve normal dağılım sergilediği görülmüştür (Hair ve diğ., 2009: 73). Değerlerin belirtilen aralıkta olması sebebiyle verilerin normal dağılım gösterdiği kabul edilmiştir. Analizlerde açıklayıcı model olarak temel bileşenler analizi ve dik döndürme (varimaks rotasyon) seçenekleri kullanılmıştır. Örneklem büyüklüğünün faktör analizine uygunluğunu gösteren $\mathrm{KMO}$ değeri hesaplanmış ve 0,807 olarak bulunmuştur. Verilerin faktör analizine uygunluğunu tespit eden Bartlett Küresellik testi anlamlı $(p<0.000)$ bulunmuştur.

Tablo 2: Öıçeğe İlişkin Doğrulayıcı Faktör Analizi Sonuçları*

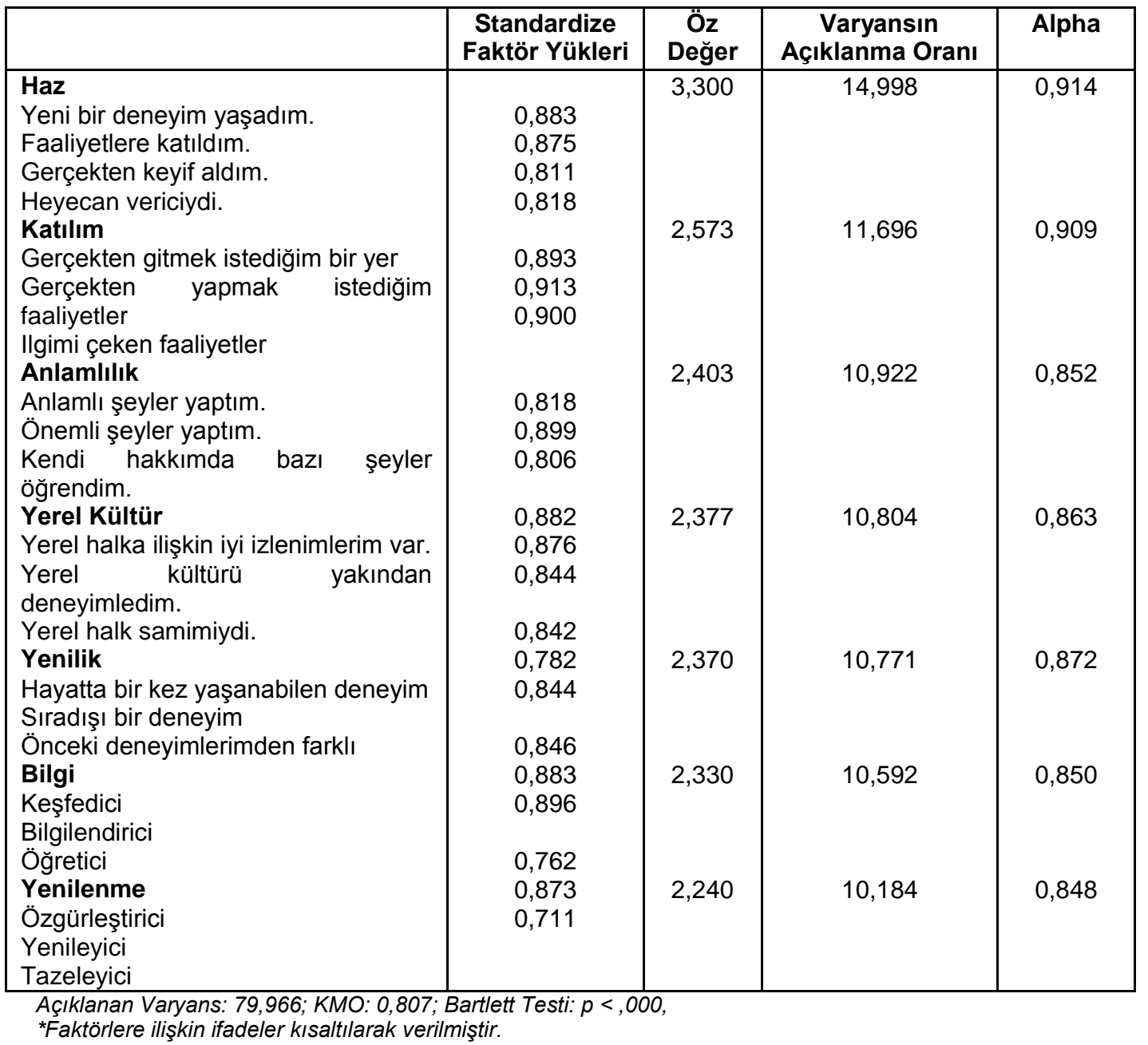


Ölçekte yer alan değişkenler arasındaki ilişki kat sayılarına ve değişkenlerin Cronbach's Alpha değerlerine bakılmıştır. Faktör yükü .30'un altında kalan ve düşük ilişki katsayısına sahip iki madde (yenilik boyutunun 4. değişkeni ile yenilenme boyutunun 1. değişkeni) analizden çıkarılmıştır. Tablo 2'de görüldüğü üzere, faktör analizi sonucunda turizm deneyimleri ölçeği yedi boyut ve 22 maddeden oluşmuştur. Genel olarak yedi faktörün varyansı toplam açıklama oranı ise $\% 79,966$ olarak elde edilmiştir. Faktörlerin varyansı açıklama oranlarına bakıldığında, hazzın daha yüksek bir açıklama oranına sahip olduğu görülmektedir.

Unutulmaz turizm deneyimleri ölçeğini oluşturan yedi faktörün güvenilirlikleri değerlendirildiğinde, hepsinin 0,80'in üzerinde olduğu görülmektedir. Bu durum tüm faktörlerin yüksek derecede güvenilir olduğunu göstermektedir.

\subsection{Polonyalı ve İranlı Turistlerin Unutulmaz Turizm Deneyimleri Arasındaki Farklılıklar}

Araştırmada Erzurum'u ziyaret eden Polonyalı ve İranlı turistlerin, kış turizmi destinasyonunda yaşadıkları unutulmaz deneyimlerin milliyetlerine göre herhangi bir farklılık gösterip göstermediğini tespit etmek amacıyla bağımsız örneklem t-testi uygulanmıştır. Test sonucunda Polonyalı ve İranlı turistlerin deneyimlerinde hissettikleri hazda 0,05 önem seviyesinde anlamlı bir farklılık $(t=2,453)$ tespit edilmiştir. Polonyalı turistlerin, İranlı turistlere oranla yaşadıkları deneyimden daha çok etkilendiği, bu süreçte heyecanlandığı ve yeni bir deneyim yaşadığını düşündüğü belirlenmiştir. Bununla birlikte, Polonyalı ve İranlı turistlerin deneyimlerini anlamlandırmaları arasında da 0,05 önem seviyesinde anlamlı bir farklılık olduğu $(t=2,788)$ görülmüştür. Polonyalı turistlerin İranlı turistlere nazaran yaşadıkları bu deneyimi daha anlamlı buldukları tespit edilmiştir. Polonyalı turistler Erzurum-Palandöken kış turizmi merkezinde yaşadıkları unutulmaz deneyimler sonucu önemli bir şey yaptıklarını ve kendileri hakkında bir şeyler öğrendiklerini daha fazla düşünmüşlerdir.

Tablo 3: Unutulmaz Turizm Deneyimi Alt Boyutlarının Milliyetlere Göre Farklılığı

\begin{tabular}{|l|l|l|l|l|l|l|}
\hline & Ülke & Sayı & Ortalama & St. Hata & t & Sig. \\
\hline Haz & Polonya & 257 & 4,4776 & 0,09593 & 2,453 & $0,015^{*}$ \\
& İan & 161 & 4,0994 & 0,12040 & & \\
\hline Katılım & Polonya & 257 & 2,1077 & 0,09143 & 1,203 & 0,230 \\
& Iran & 161 & 1,9317 & 0,11338 & & \\
\hline Anlamlıık & Polonya & 257 & 3,0545 & 0,07742 & 2,788 & $0,006^{*}$ \\
& Iran & 161 & 2,7308 & 0,07895 & & \\
\hline Yerel Kültür & Polonya & 257 & 5,0169 & 0,09030 & 0,622 & 0,535 \\
& İan & 161 & 4,9275 & 0,11035 & & \\
\hline Yenilik & Polonya & 257 & 4,0623 & 0,08889 & 1,239 & 0,216 \\
& Iran & 161 & 3,8778 & 0,12352 & & \\
\hline Bilgi & Polonya & 257 & 4,3074 & 0,10505 & 0,065 & 0,948 \\
& Iran & 161 & 4,2961 & 0,14247 & & \\
\hline Yenilenme & Polonya & 257 & 3,9546 & 0,09235 & 0,852 & 0,395 \\
& Iran & 161 & 3,8261 & 0,12085 & & \\
\hline
\end{tabular}

Analiz sonucu, katılım, yerel kültür, yenilik, bilgi ve yenilenme faktörleri açısından Polonyalı ve İranlı turistler arasında anlamlı bir farklılık bulunamamıştır. 


\section{Sonuç ve Tartışma}

Geçmiş yıllarda hizmet sektörü olarak değerlendirilen turizm, soyut terimlerden ziyade esas olarak en çarpıcı örneği deniz-kum-güneş olan somut terimlerle ifade edilmiş ve analiz edilmiştir. Bugün ise turizmin temel olarak farklı bir hayat tarzını ziyaret etme, görme ve yaşama ile ilgili olduğu yeni yeni anlaşılmaya başlanmıştır (Stamboulis, 2008: 162). Bu araştırmada da, turizmin deneyimlere odaklanan yeni doğası keşfedilmeye çalışılmıştır. Bu amaçla, Türkiye'nin en önemli kış turizmi merkezlerinden biri olarak görülen Palandöken destinasyonu, Polonyalı ve İranlı turistlerin unutulmaz turizm deneyimleri açısından değerlendirilmiştir. Ankete katılan yabancı turistlerin \%56'sı Polonyalı ve \%44'ü İranlıdır. Turistlerin yaşadıkları bu unutulmaz deneyime bakış açıları arasında bazı anlamlı farklılıklar tespit edilmiştir. Polonyalı turistlerin, haz ve anlamlılık açısından yaşadıkları deneyimi İranlı turistlerden daha olumlu algıladığı belirlenmiştir.

Özellikle son yıllarda Polonyalı turistlerin Erzurum'a charter uçuşları ile geldiği bilinmektedir. Bunda 2011 yılında yapılan Üniversitelerarası Kış Oyunları'nın da (Universiade) etkisi olduğu söylenebilir. Çünkü Erzurum sahip olduğu doğal kayak alanları yanı sıra Universiade ile birlikte kış sporlarına imkan sağlayan birçok tesisi de altyapısına kazandırmıştır. Bu nedenle hem yabancı turistler hem de sporculara yönelik unutulmaz bir kış tatili sunabilecek potansiyele sahiptir. İranlı turistler ise konum olarak Erzurum'a yakın olmanın avantajını kullanmakta ve özellikle kış sezonu boyunca destinasyonu ziyaret etmektedir. Bu ziyaretler çoğu zaman turlarla gerçekleşse de günübirlik gelişlerin olduğu da görülmektedir. Önceki çalışmalarda özellikle İranlı turistlerin Erzurum'u daha çok eğlence arzının genişliği sebebiyle tercih ettiği bilinmektedir.

Araştırma sonuçları da bu bilgileri destekler nitelikte olup, Polonyalı turistlerin Erzurum'da geçirdiği tatil deneyimlerinin, haz duyma ve anlamlandıma açısından İranlı turistlerden farklı olduğunu göstermektedir. Polonyalı turistler kış turizmi ile ilgili birçok sportif faaliyete katılarak deneyimlerinde gerçekten eğlendiğini ve heyecanlandığı, bu sebeple de yeni bir deneyim yaşadığını belirtirken, İranlı turistler bu anlamda Polonyalı turistlerden farklılaşmaktadır. Bununla birlikte Polonyalı turistler daha çok kış sporuna yönelik faaliyetleri gerçekleştirerek, tatillerini amacına ulaştırma ve anlamlandırma açısından İranlı turistlerden farklılaşmaktadır.

Kim (2013) Amerika ve Tayvan'daki üniversite öğrencilerinin unutulmaz turizm deneyimlerini karşılaştırmış ve yedi faktörün beşinde (haz, yenilenme, yenilik, anlamlılık ve bilgi) iki grup arasında belirgin bir farklılık olduğunu tespit etmiştir. Bununla birlikte yerel kültür ve katılım faktörleri her iki grup tarafından da önemli algılanmıştır. Çalışma ile her bir grup için ayrı turizm programları tasarlarken ve geliştirirken hangi unutulmaz turizm deneyimi faktörlerine vurgu yapılması gerektiği ve kültürel oryantasyon dikkate alınmaksızın tüm ziyaretçiler için hangi önemli ortak faktörlerin tatmin edilebileceği ortaya konmuştur. Bu araştırmada da, Polonyalı turistlerin, haz ve anlamlılık açısından yaşadıkları kış turizmi deneyimini İranlı turistlerden daha olumlu algıladığı belirlenmiştir. Bu sayede Erzurum'u en sık ziyaret eden iki milliyetten turistlerin deneyimleri dikkate alınarak geliştirilecek turizm planlarına fikir sağlamak amaçlanmıştır. Daha önce bu iki milliyetin turizm deneyimleri arasındaki farklılıklara odaklanan herhangi bir araştırmaya rastlanamasa da, özellikle turizm araştırmalarında kültürlerarası karşılaştırmalar sıklıkla görülmektedir.

Daha önceki kültürlerarası araştırmalar, turizm deneyimlerinin kültürel geçmişe göre değişebileceğini göstermektedir. Bu çalışmalar turizm deneyimleri literatürüne 
önemli katkılarda bulunmuş olsa da, turizm deneyimlerinin farklı aşamalarını kapsayan çalışmalar sınırlıdır. Kültürlerarası çalışmalardan hiçbiri, davranışsal niyette belirgin bir etkiye sahip olan turizm deneyimlerinin hatırlanabilirliği yani unutulmazlığına odaklanmamaktadır (Kim, 2013: 340). Bu araştırmada ise farklı milliyetlerin unutulmaz turizm deneyimleri değerlendirilmiş ve turistlerin milliyetlerine göre bu deneyimlerin farklılaştığı noktalar tespit edilmiştir. Bu sebeple destinasyon yöneticilerinin uluslararası turistler için daha etkin bir turizm programı tasarlamada bu araştırma sonuçlarından yararlanabileceği düşünülmektedir.

\section{1. Öneriler}

Erzurum'u kış turizmi amacıyla ziyaret eden Polonyalı ve İranlı turistlerin, destinasyonda yaşadığı deneyimi katılım, yerel kültür, yenilik, bilgi ve yenilenme açısından benzer bulduğu tespit edilmiştir. Tüm bu faktörler her iki milliyet açısından da eşit öneme sahiptir. Bu nedenle katılımla ilgili olarak destinasyon yöneticileri, turistlerin aktif olarak katılabileceği programlar tasarlayarak katılım düzeyini artırabilir. Bununla birlikte, ziyaretçilere "bakmanın" ötesinde "orada olma" hissini yaşatan çoklu-duyusal katılım (Markwell, 2004) ve turistlere sunulan deneyimin ortak yaratıcısı olma fırsatı, deneyimleri zenginleştirecektir. Çoklu duyusal katılım ile turist tam anlamıyla deneyimin içine daldığı için unutulmazlık artacaktır. Benzer şekilde ortak yaratım süreci de turistin deneyime dahil olduğunu yani etkinliğin içinde olduğunu hissetmesine neden olacaktır. Bunun için sunulan ya da sunulması planlanan deneyimsel faaliyetlerin turistlerle işbirliği içerisinde değerlendirilmesi, turistlerin faaliyetler hakkında geri dönüş yapmalarına olanak tanınması ve turistlere fikirlerini paylaşma imkânı vererek faaliyetlerin zenginleştirilmesine çalışılmalıdır. Örneğin, kullanıcılar tarafından oluşturulan mobil uygulamalar ile ortak-yaratım ve buna yönelik bir uğraş ile destinasyon deneyimi sağlanabilir. Bununla birlikte seyahat öncesi ya da destinasyona varmadan önceki süreçlerde deneyim sağlamaya yönelik bazı uygulamalar yapılabilir. Entegre haritalar, fiyat aralığı ve etkinlikler ile birlikte interaktif seyahat planlayıcılar aracılığıyla seyahat öncesi deneyim sağlanabiliyorken, videolar, resimler ve kullanıcı hikayelerini içeren websiteleri aracılığıyla destinasyon öncesi deneyimler sağlanmaktadır. Özellikle Erzurum için uygulanabilirliği yüksek olan, daha fazla mekân bilgisi sağlamak için arttırılmış gerçeklik uygulamaları aracılığıyla destinasyon navigasyonu sağlanabilir. Ayrıca, şu an Erzurum'da tablet teknolojisi ile restoran deneyimi sunulmaktadır. Ancak bunun çok verimli bir şekilde işlemediği görülmektedir. $\mathrm{Bu}$ uygulamanın deneyimsel turizme yönelik algı arttırılarak desteklenmesi gerekmektedir. Bununla birlikte, restoran ya da kafelerde çalışan personel ve misafir arasında sosyal medya etkileşimi aracılığıyla müşteri deneyimi sağlanmasına yönelik uygulamalar mevcut olup, bunun uygulanabilirliği tartışılabilir.

Hem Polonyalı hem de İranlı turistler açısından eşit öneme sahip yerel kültür faktörüne ilişkin turizm deneyimlerini arttırabilmek için, turistlerin yerel kültürü yakından deneyimleyebilecekleri turizm programları geliştirilebilir. Örneğin tarihi değerler ile birlikte yerel kültürü yansıtan önemli mekânlara gerçekleştirilecek turlar, kişisel deneyimlerin zenginleştirilmesinde büyük bir etkiye sahip olacaktır. Bu kültür turizmi programları yanı sıra, turistlerin park ve pazar gibi yerel halkın yaşam biçimini gözlemleyebilecekleri ziyaret yerleri, bir kişinin yerel kültüre ilişkin deneyimini yoğunlaştıracaktır. Bu sebeple sahip olduğu geleneksel atmosfer ve otantik yapı ile yabancı turistleri etkileyen Erzurum'a özellikle charter uçuşları ile gelen her Polonyalı turist kafilesi için çeşitli kültür turları planlanarak turistlerin yaşadığı deneyim en üst seviyeye çıkarılabilir. Özellikle yerel paydaşların yapacağı ya da yapmayı planladığı geleneksel girişimler desteklenmeli, Palandöken dağında konuşlanmış konaklama işletmeleri diğer tüm yöresel turizm işletmeleri ile işbirliği kurarak turistlere daha üst 
seviyede bir deneyim yaşatmalıdır. Aksi takdirde özellikle Polonyalı turistler şehrin geleneksel havasını solumadan otelinde konaklayacak ve yerel kültüre dair bir fikre sahip olmadığı gibi turizm deneyimlerinin en önemli bileşenlerinden biri olan özgünlüğü bulamayacaktır.

Bilgi faktörünü etkinleştirmek için ise pazarlamacılar destinasyonun eğitim avantajlarına odaklanmalıdır. Tarih, kültür, yemek ve sanat gibi destinasyon hakkında bilgi sağlayan programlar ve ortamlar, Polonyalı ve İranlı turistlere unutulmaz turizm deneyimler yaşatılmasına yardımcı olacaktır. Bununla birlikte turistlerin özgürleşme, yenilenme ve tazelenme duygusunun keyfini çıkarabileceği ortamlar yaratmak, turizm deneyiminin unutulmazlığını önemli ölçüde etkileyecektir.

Polonyalı turistler ile İranlı turistler arasında haz ve anlamlılık açısından yaşanan kış turizmi deneyiminin farklı olmasının sebebi, Polonyalı turistlerin benzer iklim koşullarına sahip olmaları ve kendi ülkelerinde de kış turizmi faaliyetlerine katılmaları olabilir. Ancak İranlı turistlerin değişik bir coğrafyadan geldiği için genellikle bu farklıığın tadını çıkardığı ancak kış turizmi faaliyetlerine çok katılmadığı gözlenmektedir. Destinasyon yöneticileri bu farklılıklara dikkat etmeli ve her ulusal grup için ayrı programlar sunmalıdır. Örneğin, Polonyalı genç yetişkin gezginlerin, hazcı deneyimleri hatırlama olasılıkları daha yüksektir. Program içerikleri ve çevresel ipuçları ziyaretçiler tarafından algılanan haz düzeyini etkilediği (Grappi ve Montanari, 2011: 1137) için destinasyon yöneticileri programları ve çevresel atmosferi dikkatle geliştirmelidir. Özellikle programların heyecan verici, keyifli, eğlenceli ve ilginç olarak algılanması için dikkatli bir şekilde tasarlanması gerekir. Bununla birlikte İranlı turistlerden daha fazla olmak üzere Polonyalı turistler bu turizm deneyimi sayesinde anlamlı ve önemli şeyler yanı sıra kendine dair bir şeyler de öğrendiğini düşünmektedir.

Rekabet avantajı sağlayacak şekilde unutulmaz deneyimler sunulmak isteniyorsa, keyifli deneyimlere yönelik daha kapsamlı bir anlayış geliştirilmeli ve bunun tasarımının sistematik bir yaklaşım ile iyi bir şekilde sunulması gerekmektedir (Le Bel, 2005: 438). Aslında temel hedef, ziyaretçiler için unutulmaz destinasyon deneyimleri sağlayan programların yeterliliği ve etkinliğini iyi bir şekilde değerlendirmekten geçmektedir (Ritchie ve Crouch, 2000: 4).

Erzurum turizminde rekabetçiliği arttırmayı sağlayacak turist deneyimlerinin keşfedilmesi, Erzurum turizmi ile ilgilenen yatırımcılar için önemli bilgiler sunmaktadır. Öncelikle bu bilgilerin öneminin özellikle turizm sektörü paydaşları tarafından anlaşılmasına çalışılmalıdır. Deneyimsel turizm faaliyetlerinin bir destinasyonu rakiplerine karşı öne çıkaracak en önemli avantajlardan biri olarak görmeleri ve bunu içselleştirmelerine yönelik çalışmalar yapılmalıdır.

Mevcut turizm deneyimi anlayışının yeniden değerlendirilmesi ve yeni şeyler keşfedilmesi için sürekli bir çabaya ihtiyaç vardır, bu nedenle sürekli araştırılması gerekmektedir. Sunulan öneriler sadece mevcut durumun anlık görüntüsünü sağlarken, şüphesiz birçok soru cevapsız kalmaktadır ve deneyim yaratmaya yönelik gelecekteki gelişmeleri anlamak için daha fazla araştırma yapılmalıdır (Neuhofer ve Buhalis, 2014: 124, 136).

Literatür incelendiğinde, özellikle turizm deneyimi sırasındaki duygusal süreçlere yönelik daha fazla araştırmaya intiyaç duyulduğu gözlenmiştir. Literatürdeki mevcut durum, hem hizmet kalitesi hem de deneyimsel bakış açısından bazı büyük gelişmeler olduğunu göstermektedir, fakat gelecek yıllarda özellikle turizm bağlamında 
deneyimsel tüketimin anlaşıımasına fayda sağlayacak daha farklı araştırma projelerinin ortaya konması gerekmektedir (Batat ve Frochot, 2014: 121).

$\mathrm{Bu}$ araştırmada uygulama alanı olarak bir kış turizmi destinasyonu olan Erzurum seçilmiştir. Ancak uygulama alanı çeşitlendirilebilir ve birçok farklı destinasyona uyarlanabilir. Bununla birlikte müzeler, hayvanat bahçeleri, tarihi ve kültürel mekânlara vb. yönelik deneyimsel turizm çalışmaları da yapılabilir. Özellikle müzecilikte yeni bir biçim olan ve genellikle etkileşimsel yapıya sahip ekomüzeler ile artan deneyimsel turizm talebinin karşılandığı (Salazar ve Zhu, 2015: 242) düşünüldüğünde bu alana yönelik çalışmaların orjinallik taşıyacağı söylenebilir.

Araştırmada örneklem Erzurum'a kış turizmi amacıyla en fazla gelen iki farklı milliyet ile sınırlandırılmıştır. Ancak bu karşılaştırma daha fazla milliyetten turisti kapsayacak şekilde genişletilebilir. Ayrıca, bu çalışmada turizm deneyimlerini ölçmek amacıyla yapılan uygulama seyahat sonrasını kapsamaktadır. Gelecek araştırmalarda ise deneyimsel turizmin çoklu seviyelerini değerlendirebilmek amacıyla seyahat öncesi, seyahat sırası ve sonrasındaki farklııklar değerlendirilebilir. Çalışmada turistlerin sadece yaş ve cinsiyetlerine ilişkin bilgiler irdelenmiştir, sonraki araştırmalarda meslek ve eğitim durumu gibi diğer değişkenlere ilişkin sorular sorularak demografik değişkenlere gore deneyimlerinin farklılaşıp farklılaşmadığı da araştırılabilir.

\section{Kaynakça}

Akkuş, G. (2016), Destinasyon Rekabetçiliği İçin Deneyimsel Turizm: Turist Perspektifinden Bir Değerlendirme, Yayınlanmamış Doktora Tezi, Atatürk Üniversitesi, Sosyal Bilimler Enstitüsü, Erzurum.

Altunışık, R., Coşkun, R., Bayraktaroğlu, S., Yıldırım, E. (2012), Sosyal Bilimlerde Araştırma Yöntemleri SPSS Uygulamalı, Geliştirilmiş 7. Baskı, Sakarya: Sakarya Yayıncılık.

Arsenault, N. ve Gale, T. (2004). Defining Tomorrows Tourism Product: Packaging Experiences. Araştırma Raporu (Rapor No: 2004-7). Kanada: Kanada Turizm Komisyonu.

Batat, W. ve Frochot, I. (2014), 'Towards an Experiential Approach in Tourism Studies' İçinde S. McCabe (Editör), The Routledge Handbook of Tourism Marketing, ss. 109-123. Oxon \& New York: Routledge.

Edgell, D. L., Allen, M. D., Smith, G., ve Swanson, J. R. (2014), Tourism Policy and Planning: Yesterday, Today and Tomorrow, Oxon \& New York: Routledge.

Goldsmith, R. E. ve Tsiotsou, R. H. (2012). 'Introduction to Experiential Marketing'. İçinde R. H. Tsiotsou ve R. E. Goldsmith (Editörler), Strategic Marketing in Tourism Services, ss. 207-214, UK: Emerald Group Publishing Limited.

Grappi, S. ve Montanari, F. (2011), 'The Role of Social Identification and Hedonism Affecting Tourist Re-Patronizing Behaviours: The Case of an Italian Festival' Tourism Management, 32(5), ss. 1128-1140.

Hair, J. F., Black, W. C., Babin, B. J. ve Anderson, R. E. (2009), Multivariate Data Analysis, 7. Baskı, USA: Prentice Hall.

Hançer, M. (2003). 'Ölçeklerin Yazım Dilinden Başka Bir Dile Çevirileri ve Kullanılan Değişik Yaklaşımlar', Balıkesir Üniversitesi Sosyal Bilimler Enstitüsü Dergisi, 6(10), ss. 47-59.

Jennings, G., Lee, Y.-S., Ayling, A., Lunny, B., Cater, C. ve Ollenburg, C. (2009), 'Quality Tourism Experiences: Reviews, Reflections, Research Agendas', Journal of Hospitality Marketing \& Management, 18(2-3), ss. 294-310. 
Kay, P. L. (2009), 'Cultural Experience Tourist Motives Dimensionality: A CrossCultural Study', Journal of Hospitality Marketing \& Management, 18(4), ss. 329371.

Kim, J.-H. (2009), Development of a Scale to Measure Memorable Tourism Experiences, Yayınlanmış Doktora Tezi, Indiana University, School of Health, Physical Education, and Recreation, Indiana.

Kim, S. (2012), 'A Cross-Cultural Study of On-Site Film-Tourism Experience among Chinese, Japanese, Taiwanese and Thai Visitors to the Daejanggeum Theme Park, South Korea', Current Issues in Tourism, 15(8), ss. 759-776.

Kim, J.-H., Ritchie, J. R. B. ve McCormick, B. (2012), 'Development of a Scale to Measure Memorable Tourism Experiences', Journal of Travel Research, 51(1), ss. $12-25$.

Kim, J.-H. (2013), 'A Cross-Cultural Comparison of Memorable Tourism Experiences of American and Taiwanese College Students', Anatolia - An International Journal of Tourism and Hospitality Research, 24(3), ss. 337-351.

Kim, J.-H. (2014), 'The Antecedents of Memorable Tourism Experiences: The Development of a Scale to Measure the Destination Attributes Associated with Memorable Experiences', Tourism Management, 44, ss. 34-45.

Kim, J.-H. ve Ritchie, J. R. B. (2014), 'Cross-Cultural Validation of a Memorable Tourism Experience Scale (MTES)', Journal of Travel Research, 53(3), ss. 323335.

Kozak, M. (2001), 'Comparative Assessment of Tourist Satisfaction with Destinations across Two Nationalities', Tourism Management, 22, ss. 391-401.

Larsen, S. (2007), 'Aspects of a Psychology of the Tourist Experience', Scandinavian Journal of Hospitality and Tourism, 7(1), ss. 7-18.

Le Bel, J. L. (2005), 'Beyond the Friendly Skies: An Integrative Framework for Managing the Air Travel Experience', Managing Service Quality: An International Journal, 15(5), ss. 437-451.

Li, Y. (2000), 'Geographical Consciousness and Tourism Experience', Annals of Tourism Research, 27(4), ss. 863-883.

Markwell, K. (2004), 'Constructing, Presenting and Interpreting Nature: A Case Study of a Naturebased Tour to Borneo', Annals of Leisure Research, 7(1), ss. 19-33.

McCabe, S. (2014), 'Introduction' İçinde S. McCabe (Editör), The Routledge Handbook of Tourism Marketing, ss. 1-12. Oxon \& New York: Routledge.

Neuhofer, B. ve Buhalis, D. (2014), 'Experience, Co-creation and Technology: Issues, Challenges and Trends for Technology Enhanced Tourism Experiences' İçinde S. McCabe (Editör), The Routledge Handbook of Tourism Marketing, ss. 124139. Oxon \& New York: Routledge.

O'dell, T. (2007), 'Tourist Experiences and Academic Junctures', Scandinavian Journal of Hospitality and Tourism, 7(1), ss. 34-45.

Oral, S. ve Çelik, A. (2013), 'Türkiye'yi Ziyaret Eden Turistlerin Estetik Deneyimleri Üzerine Bir Araştırma', İşletme Araştırmaları Dergisi, 5(4), ss.170-190.

Otto, J. E. ve Ritchie, J. R. B. (1996), 'The Service Experience in Tourism', Tourism Management, 17(3), ss. 165-174.

Özmen, A. (2009), 'Örnekleme' İçinde A. F. Yüzer (Editör), İstatistik, ss. 167-194. Eskişehir: Anadolu Üniversitesi YayınıNo: 1448, Açıköğretim Fakültesi Yayını No: 771.

Pine II, B. J. ve Gilmore, J. H. (1999), The Experience Economy: Work Is Theatre and Every Business a Stage, Boston-Massachusetts: Harvard Business School Press.

Pizam, A., ve Jeong, G. (1996), 'Cross-Cultural Tourist Behavior Perceptions of Korean Tour-Guides', Tourism Management, 17(4), ss. 277-286. 
Pizam, A., ve Reichel, A. (1995), 'Does Nationality Affect Tourist Behavior?', Annals of Tourism Research, 22(4), ss. 901-916.

Pizam, A., ve Reichel, A. (1996), 'The Effect of Nationality on Tourist Behavior: Israeli Tour Guides' Perceptions', Journal of Hospitality and Leisure Marketing, 4(1), ss. 23-49.

Prahalad, C. K. ve Ramaswamy, V. (2004), 'Co-Creation Experiences: The Next Practice in Value Creation'. Journal of Interactive Marketing, 18(3), ss. 5-14.

Reisinger, Y., Mavondo, F. T. ve Crotts, J. C. (2009), 'The Importance of Destination Attributes: Western and Asian Visitors', Anatolia - An International Journal of Tourism and Hospitality Research, 20(1), ss. 236-253.

Rettie, K. (2013), 'A Culture of Conservation: Shaping the Human Element in National Parks' Içinde J. G. Carrier ve P. West (Editörler), Virtualism, Governance and Practice: Vision and Execution in Environmental Conservation, ss. 66-83. USA: Berghahn Books.

Ritchie, J. R. B. ve Crouch, G. I. (2000), 'The Competitive Destination: A Sustainability Perspective', Tourism Management, 21(1), ss. 1-7.

Ritchie, J. R. B. ve Crouch, G. I. (2003), The Competitive Destination-A Sustainable Tourism Perspective, UK: CABI Publishing.

Ritchie, J. R. B., Tung, V. W. S. ve Ritchie, R. J. B. (2011), 'Tourism Experience Management Research: Emergence, Evolution and Future Directions', International Journal of Contemporary Hospitality Management, 23(4), ss. 419438.

Salazar, N. B. ve Zhu, Y. (2015), 'Heritage and Tourism' Içinde L. Meskell (Editör),

Global Heritage: A Reader, ss. 240-258. UK: John Wiley \& Sons.

Selstad, L. (2007), 'The Social Anthropology of the Tourist Experience. Exploring the 'Middle Role', Scandinavian Journal of Hospitality and Tourism, 7(1), ss. 19-33.

Smith, M. K. (2009). Issues in Cultural Tourism Studies Second Edition [Elektronik Sürüm]. Londra: Routledge.

Stickdorn, M. (2014), 'Service Design: Co-creating Meaningful Experiences with Customers' İçinde S. McCabe (Editör), The Routledge Handbook of Tourism Marketing, ss. 329-344. Oxon \& New York: Routledge.

Stamboulis, Y. ve Skayannis, P. (2003), 'Innovation Strategies and Technology for Experience-Based Tourism', Tourism Management, 24(1), ss. 35-43.

Stamboulis, Y. (2008), 'Destinations as Experience Stages: A System View' İçinde S. Babu, S. Mishra, B. B. Parida (Editörler), Tourism Development Revisited: Concepts, Issues and Paradigms, ss. 161-176. New Delhi: SAGE Publications.

Toy, S., Eymirli, E. B. ve Karapınar, M. (2010), Erzurum Konaklı Bölgesi Kış Turizm Merkezi Raporu, (Turizm Raporları No:2), Erzurum: Kuzeydoğu Anadolu Kalkınma Ajansı (KUDAKA).

Tussyadiah, I. P. ve Fesenmaier, D. R. (2009), 'Mediating Tourist Experiences: Access to Places via Shared Videos', Annals of Tourism Research, 36(1), ss. 24-40. 